\title{
Biomarkers in newborns with hypoxic-ischemic encephalopathy treated with therapeutic hypothermia
}

\author{
Barbara Michniewicz $^{1}$ - Dawid Szpecht ${ }^{1}$ (D) Anna Sowińska ${ }^{2} \cdot$ Rafał Sibiak $^{3} \cdot$ Marta Szymankiewicz $^{1}$. \\ Janusz Gadzinowski ${ }^{1}$
}

Received: 11 March 2020 / Accepted: 24 April 2020 / Published online: 4 May 2020

(C) The Author(s) 2020

\begin{abstract}
Purpose The aim of the presented study was to evaluate the differences between selected biochemical markers in infants with moderate or severe hypoxic-ischemic encephalopathy (HIE) and their impact on patient prognosis.

Methods A total of 57 cooled newborns were divided into groups according to Sarnat staging of HIE (A, moderate vs. B, severe). The differences between groups were evaluated depending on the mode of delivery, pregnancy and labor complications, gestational age at birth, birth weight, and Apgar score at 1.3 and $5 \mathrm{~min}$. The differences in biochemical biomarkers of HIE (pH, base excess, serum lactate) as well as biomarkers of hepatic injury (aspartate transaminase, (AST), alanine transaminase (ALT), prothrombin time (PT), and activated partial thromboplastin time (APTT)), kidney failure (creatinine, urea), myocardial injury (troponin T (TnT)), levels of fibrinogen, and platelet counts were also examined. Univariate Kaplan-Meier method was used for survival analyses.

Results The biomarker levels in severe HIE newborns compared with moderate were as follows: pH (7.10 vs. 6.99), serum lactate (22.50 vs. $17.00 \mathrm{mg} / \mathrm{dL})$, AST (109.50 vs. $270.55 \mathrm{IU} / \mathrm{L})$, ALT (27.30 vs. $108.05 \mathrm{IU} / \mathrm{L})$, PT (17.00 vs. $44.20 \mathrm{~s})$, APTT (47.75 vs. $47.90 \mathrm{~s})$, TnT (0.22 vs. $0.85 \mathrm{ng} / \mathrm{mL})$, creatinine (0.68 vs. $1.15 \mathrm{mg} / \mathrm{dL})$, urea (44.55 vs. $73.30 \mathrm{mg} / \mathrm{dL})$, and fibrinogen $(1.65 \mathrm{vs}$. $1.90 \mathrm{mg} / \mathrm{dL})$. Survival analyses showed significantly reduced survival for severe HIE infants (75\%) vs. moderate HIE (100\%). Conclusion In conclusion, the severity of HIE can be evaluated based on selected markers; however, their levels do not correspond with future prognosis of newborns.
\end{abstract}

Keywords Perinatal asphyxia $\cdot$ Hepatic enzymes $\cdot$ Kidney failure $\cdot$ Troponin $\mathrm{T}$

\section{Introduction}

Neonatal encephalopathy (NE) is a term used to describe a neurological syndrome caused by a disorder of the brain. Clinical manifestations of NE include features of altered level of consciousness, respiratory depression, seizures, and abnormal muscle tone and reflexes [1]. NE occurs most often as a result of acute hypoxic-ischemic insult, intracranial

Dawid Szpecht

dawid.szpecht@poczta.fm

1 Department of Neonatology, Poznan University of Medical Sciences, Poznan, Poland

2 Department of Computer Science and Statistics, Poznan University of Medical Sciences, Poznan, Poland

3 Poznan University of Medical Sciences, Poznan, Poland hemorrhages, numerous metabolic disorders, intrauterine infections, and epileptic syndromes [1, 2]. Hypoxic-ischemic encephalopathy (HIE) is classified as a subtype of NE with characteristic lesions observed in an MRI [1]. The incidence of HIE is estimated to be between 1.3 and 1.7 per 1000 live births [3].

HIE is associated with increased risk of neonatal mortality; $15-20 \%$ of neonates die due to complications of perinatal asphyxia [3]. Moreover, HIE often leads to sustained severe and irreversible brain damage. Further observations of infants affected by perinatal asphyxia revealed that $27-33 \%$ of them at an age of 6 to 7 years will develop features of intellectual disability (IQ under 70 and deficits in adaptive behaviors) [4]. Patients frequently present a broad spectrum of other neurological symptoms, such as motor dysfunction, hearing loss, impaired vision, epilepsy, and behavioral problems, which occur as a consequence of a perinatal hypoxic-ischemic episode. A diagnosis of cerebral palsy was confirmed in 17-29\% of children with a history of perinatal asphyxia [4-6]. 
Evaluation of the severity of HIE is a crucial determinant in predicting the future outcomes for children with HIE. Physical examination combined with neurological assessment, performed according to Sarnat staging [7], gives us reliable information about the future prognosis. Previous studies revealed a group of plasma biomarkers (S100B, UCH-L1, total Tau, neuron-specific enolase, brain-derived neurotrophic factor (BDNF), and inflammatory cytokines), which can be useful in assessing the extent of brain damage. Furthermore, baseline Tau and BDNF levels correlate with worse 1-year outcomes $[8,9]$. However, perinatal asphyxia can disrupt functioning of other internal organs. Measurement of the concentration of specific serum and urinary biomarkers can be helpful in early detection of hypoxic-ischemic injury of the kidneys, liver, and heart [10-12].

Meta-analyses of previous studies showed that therapeutic hypothermia $(\mathrm{TH})$ reduces mortality and neurodevelopmental disability in groups of term or late preterm newborns with suspicion of peripartum asphyxia [13]. Before initiation of therapeutic cooling, infants must fulfill certain eligibility criteria. Cooling should be performed according to standardized selective head cooling (SHC) or whole-body cooling (WBC) protocols. Results of recent clinical trials revealed that both methods - SHC and WBC - have proven to have a neuroprotective effect [14-16]. As a result, hypothermia has emerged as the standard of care to infants with moderatesevere HIE.

Taking into consideration that early evaluation of severity of HIE, as well as early detection of potential multiorgan injury caused by asphyxia in diagnosed neonates, can be helpful in the prognosis of newborns' outcomes; the aim of the presented study was to assess whether the differences between selected biochemical markers in infants with moderate or severe HIE affect the future patient's prognosis.

\section{Methods}

\section{Patients and inclusion criteria}

A retrospective study of 57 neonatal patients with diagnosed HIE was conducted in the Department of Neonatology at Poznan University of Medical Sciences between 2009 and 2017. Therapeutic hypothermia was introduced into the standard clinical practice for infants born $\geq 36$ weeks of gestation with suspected perinatal asphyxia within $6 \mathrm{~h}$ after birth. Before the application of $\mathrm{TH}$, newborns with presumed HIE were evaluated in accordance with specific eligibility criteria. All patients enrolled in the study met both treatment criteria $\mathrm{A}$ and B. Criterion A included at least one of the following conditions: (1) acidosis of arterial blood or the blood obtained from the umbilical cord ( $\mathrm{pH}<7.00$, within 60 min after birth) or base excess $(\mathrm{BE}) \geq 16 \mathrm{mmol} / \mathrm{l}$; (2) Apgar score $\leq 5$ at
10 min after birth; and (3) resuscitation $\geq 10$ min after birth. Criterion B included patients with moderate-to-severe HIE according to Sarnat staging, especially with a state of impaired consciousness (lethargy or coma), and with at least one additional feature such as decreased muscle tone, abnormal stimulus response (oculomotor nerve impairment, abnormal pupillary light reflex, weak or absent suck reflex), and clinically proven seizures. Before induction of the cooling procedure, the patient's brain activity was assessed for at least $20 \mathrm{~min}$ using an amplitude-integrated electroencephalogram (aEEG). All of the aEEG records presented features of moderate or severe brain dysfunction and seizures. Moderately abnormal aEEGs were defined as visible changes in the activity band (discontinuous background pattern - lower margin of the band $<5 \mu \mathrm{V}$ ). The presence of burst suppression, low continuous voltage, or flat tracing in recorded activity band was classified as patterns of severely abnormal aEEG $[17,18]$.

\section{Cooling protocol}

Patients were cooled with a selective head cooling Cool-Cap system (14 neonates) and a whole-body cooling device (Nz Techno, Tecotherm, 43 neonates). After application of therapeutic hypothermia, neonates were cooled for $72 \mathrm{~h}$. Selective head cooling (SHC) and whole-body cooling (WBC) require a continuous body (rectal) temperature measurement. During $\mathrm{SHC}$, the core body temperature was reduced to $34.5^{\circ} \mathrm{C}$. In a group of patients cooled with WBC, core temperature was maintained at $33.0-33.5^{\circ} \mathrm{C}$. After that, the patients were slowly rewarmed $\left(0.5^{\circ} \mathrm{C} / \mathrm{h}\right)$ to $36.5^{\circ} \mathrm{C}$.

\section{Analyzed parameters}

Newborns were divided into groups according to Sarnat staging of HIE (group A, grade II moderate vs. group B, grade III severe). The differences between groups were evaluated depending on the mode of delivery, pregnancy and labor complications, gestational age at birth, birth weight, and Apgar score at 1.3 and $5 \mathrm{~min}$. The differences in biochemical plasma biomarkers of HIE were also evaluated. The comparison of metabolic acidosis parameters ( $\mathrm{pH}$ and base excess) was performed on fetal umbilical cord arterial blood samples obtained immediately after birth. The measurements of $\mathrm{pH}$, base excess, and level of serum lactate were carried out on two additional specimens of blood obtained from umbilical vessels after $1 \mathrm{~h}$ and at latest after $4 \mathrm{~h}$ after birth. The levels of plasma biomarkers of hepatic injury (aspartate transaminase (AST), alanine transaminase (ALT), prothrombin time (PT), and activated partial thromboplastin time (APTT)), kidney failure (creatinine, urea), myocardial injury (troponin T, TnT), levels of fibrinogen, and platelet counts were also examined. All blood samples were collected in the first $24 \mathrm{~h}$ after birth. 


\section{Statistical analysis}

Statistical analysis was performed using Statistica. Descriptive statistics are presented as percentages for categorical variables, mean and standard deviation for continuous, normally distributed variables, and median with range for continuous variables with asymmetry of distribution. Normality of the distributions was checked by Shapiro-Wilk test. The prevalence of variables was assessed by the chi square test, the Fisher exact test, or Fisher-Freeman test. Continuous variables were compared using the Mann-Whitney $U$ test, Student's $t$ test, or Cochran-Cox test.

\section{Results}

A total of 57 neonatal patients were enrolled in the study. Table 1 shows the baseline characteristics of the 57 neonates analyzed (Table 1). The vast majority of them (45 out of 57) were transferred from other institutions to the tertiary referral hospital within $6 \mathrm{~h}$ after birth. Pregnancy or labor complications occurred in 45 out of 57 (78.9\%) of the patients. The other most common complications were placental abruption (15 out of 57 cases), meconium-stained amniotic fluid (12 out

Table 1 Demographic and clinical characteristics of enrolled infants

\begin{tabular}{llll}
\hline & $\begin{array}{l}\text { Group with moderate } \\
\text { HIE } n=27(\%)\end{array}$ & $\begin{array}{l}\text { Group with severe } \\
\text { HIE } n=30(\%)\end{array}$ & $p$ value \\
\hline Gender & & & $0.678^{\mathrm{a}}$ \\
Male & 13 & 18 & \\
Female & 14 & 12 & $0.061^{\mathrm{d}}$ \\
$\begin{array}{c}\text { Gestational } \\
\text { age (week) }\end{array}$ & $36(36-42)$ & $38(36-41)$ & $0.958^{\mathrm{e}}$ \\
$\begin{array}{c}\text { Birth weight } \\
\quad \text { gram) }\end{array}$ & $3314.25 \pm 507.78$ & $3306.16 \pm 641.89$ & \\
$\begin{array}{c}\text { Mode of } \\
\text { delivery }\end{array}$ & & & $0.397^{\mathrm{b}}$ \\
Forceps & 2 & & \\
Vaginal & 3 & 0 & \\
Vacuum & 1 & 7 & \\
Cesarean & 21 & 1 & $0.837^{\mathrm{a}}$ \\
$\quad$ section & & 22 & \\
Inborn & 6 & 6 & $0.0049^{\mathrm{c}}$ \\
Outborn & 21 & 24 & \\
Deaths & & 8 & \\
Yes & 0 & 22 & \\
No & 27 & & \\
\hline
\end{tabular}

${ }^{\text {a }}$ Chi-squared test

${ }^{\mathrm{b}}$ Fisher Freeman Halton

${ }^{\mathrm{c}}$ Fisher's exact test

${ }^{\mathrm{d}}$ Mann-Whitney

${ }^{\text {e }}$ Student's $t$ test of 57), intrauterine infection (8 out of 57), and gestational diabetes ( 3 out of 57). Two cases of pregnancy-induced hypertension, umbilical cord compression, and problems with fetal expulsion were also noted.

The neurological examination provided information about clinical staging of HIE. Patients were divided into groups according to Sarnat staging: 27 out of $57(47.4 \%)$ met the criteria of a group HIE - A moderate; the rest of them 30 out of $57(52.6 \%)$ were classified as cases of severe HIE - B. Statistically significant differences between the groups of moderate and severe HIE were noted (Table 2). We noticed the level of serum lactate from the first after $1 \mathrm{~h}(\mathrm{~A}, 22.50 \mathrm{mg} /$ dL (range 6.80-162.00) vs. B, $17.00 \mathrm{mg} / \mathrm{dL}$ (range 0.00 180.00)) and the second after at latest $4 \mathrm{~h}$ after birth specimen (A, $53.50 \mathrm{mg} / \mathrm{dL}$ (range $2.00-164.00$ ) vs. B, $115 \mathrm{mg} / \mathrm{dL}$ (range 14.50-186.00), $p=0.027$ ) and results of base excess in material obtained from two samples $(\mathrm{A},-15.02 \pm 5.86 \mathrm{vs}$. $\mathrm{B},-19.03 \pm 5.53, p=0.016$ and $\mathrm{A},-9.06 \pm 5.80$ vs. $\mathrm{B},-$ $14.34 \pm 5.62, p=0.001)$. Statistically significant results were also observed in the levels of hepatic injury biomarkers-AST (A, 109.50 IU/L (range 21.10-819.20) vs. B, 270.55 IU/L (range 66.10-3175.00), $p=0.0004$ ), ALT (A, 27.30 IU/L (range $8.00-571.00$ ) vs. B, $108.05 \mathrm{IU} / \mathrm{L}$ (range 16.60 $1195.30), p=0.0008$ ), PT (A, $17.0 \mathrm{~s}$ (range 10.00-44.20) vs. $\mathrm{B}, 24.40 \mathrm{~s}$ (range 14.50-320.00), $p=0.0004$ ), APTT (A, $47.75 \mathrm{~s}$ (range $34.40-92.70)$ vs. B: $47.90 \mathrm{~s}$ (range 30.30 400.00 ), $p=0.302$ ); myocardial injury biomarker- $\mathrm{TnT}$ (A, $0.22 \mathrm{ng} / \mathrm{mL}$ (range $0.06-1.62$ ) vs. B, $0.85 \mathrm{ng} / \mathrm{mL}$ (range 0.05 $10.00), p<0.0001)$; and kidney failure markers - creatinine (A, $0.68 \mathrm{mg} / \mathrm{dL}$ (range $0.23-2.26$ ) vs. B, $1.15 \mathrm{mg} / \mathrm{dL}$ (range $0.63-3.16), p<0.0001$ ) and urea $(\mathrm{A}, 44.55 \mathrm{mg} / \mathrm{dL}$ (range $19.30-108.70$ ) vs. B, $73.30 \mathrm{mg} / \mathrm{dL}$ (range $32.20-137.90$ ), $p=0.002)$. Also, different levels of fibrinogen were noted (A, $1.65 \mathrm{mg} / \mathrm{dL}$ (range $0.79-3.61$ ) vs. B, $1.90 \mathrm{mg} / \mathrm{dL}$ (range $0.30-6.90), p=0.274$ ) and thrombocytopenia (platelet count $<100,000 / \mathrm{mm}^{3}$ ) was observed in $8 / 27$ cases of moderate HIE and in 20/29 cases of severe HIE $(p=0.003)$.

\section{Survival analyses}

Univariate Kaplan-Meier's analysis showed significantly reduced survival for cases with severe HIE (group B) compared with that of patients with moderate HIE (group A). While the survival probability for newborns with moderate HIE is $100 \%$, for children with severe HIE, it is only $75 \%$ (Fig. 1). However, multivariate analyses of all 57 neonates revealed that biochemical markers of hypoxia such as lactate $(p=0.100826)$, TnT $(p=0.218603)$, AST $(p=0.957588), \operatorname{ALT}(p=$ $0.285924)$, creatinine $(p=0.794386)$, or urea $(p=$ 0.306928 ) had no effect on the probability of survival of patients with HIE (Table 3 ). 
Table 2 The levels of selected biomarkers in moderate or severe HIE newborns

\begin{tabular}{|c|c|c|c|}
\hline \multirow[b]{2}{*}{ Biomarkers } & \multicolumn{2}{|l|}{ HIE } & \multirow[b]{2}{*}{$p$ value } \\
\hline & Moderate & Severe & \\
\hline $\mathrm{pH}$ from the umbilical cord 1 & $6.89(6.65-7.28)$ & $6.81(6.59-7.29)$ & $0.0627^{\mathrm{c}}$ \\
\hline Base excess 1 & $-17.24 \pm 7.50 \mathrm{mmol} / \mathrm{L}$ & $-20.67 \pm 7.67 \mathrm{mmol} / \mathrm{L}$ & $0.173^{\mathrm{a}}$ \\
\hline $\mathrm{pH}$ from the umbilical cord 2 & $6.86(6.68-7.28)$ & $6.89(6.61-7.42)$ & $0.693^{\mathrm{c}}$ \\
\hline Base excess 2 & $-15.84 \pm 5.40 \mathrm{mmol} / \mathrm{L}$ & $-18.38 \pm 5.47 \mathrm{mmol} / \mathrm{L}$ & $0.305^{\mathrm{a}}$ \\
\hline $\mathrm{pH}$ from the blood 1 & $7.10 \pm 0.18$ & $6.99 \pm 0.22$ & $0.056^{\mathrm{a}}$ \\
\hline Base excess 1 & $-15.02 \pm 5.86 \mathrm{mmol} / \mathrm{L}$ & $-19.03 \pm 5.53 \mathrm{mmol} / \mathrm{L}$ & $0.016^{\mathrm{b}}$ \\
\hline Serum lactate 1 & $22.50(6.80-162.00) \mathrm{mg} / \mathrm{dL}$ & $17.00(0.00-180.00) \mathrm{mg} / \mathrm{dL}$ & $0.979^{\mathrm{c}}$ \\
\hline $\mathrm{pH}$ from the blood 2 & $7.25(7.04-7.43)$ & $7.21(6.59-7.46)$ & $0.446^{\mathrm{c}}$ \\
\hline Base excess 2 & $-9.06 \pm 5.80 \mathrm{mmol} / \mathrm{L}$ & $-14.34 \pm 5.62 \mathrm{mmol} / \mathrm{L}$ & $0.001^{\mathrm{b}}$ \\
\hline Serum lactate 2 & $53.50(2.00-164.00) \mathrm{mg} / \mathrm{dL}$ & $115.00(14.50-186.00) \mathrm{mg} / \mathrm{dL}$ & $0.027^{\mathrm{c}}$ \\
\hline TnT & $0.22(0.06-1.62) \mathrm{ng} / \mathrm{mL}$ & $0.85(0.05-10.00) \mathrm{ng} / \mathrm{mL}$ & $0.000004^{\mathrm{c}}$ \\
\hline AST & $109.50(21.10-819.20) \mathrm{IU} / \mathrm{L}$ & $270.55(66.10-3175.00) \mathrm{IU} / \mathrm{L}$ & $0.0004^{\mathrm{c}}$ \\
\hline ALT & $27.30(8.00-571.00) \mathrm{IU} / \mathrm{L}$ & $108.05(16.60-1195.30) \mathrm{IU} / \mathrm{L}$ & $0.0008^{\mathrm{c}}$ \\
\hline Creatinine & $0.68(0.23-2.26) \mathrm{mg} / \mathrm{dL}$ & $1.15(0.63-3.16) \mathrm{mg} / \mathrm{dL}$ & $0.00006^{\mathrm{c}}$ \\
\hline Urea & $44.55(19.30-108.70) \mathrm{mg} / \mathrm{dL}$ & $73.30(32.20-137.90) \mathrm{mg} / \mathrm{dL}$ & $0.002^{\mathrm{c}}$ \\
\hline INR & $1.44(0.97-3.96)$ & $2.04(1.07-7.54)$ & $0.004^{\mathrm{c}}$ \\
\hline APTT & $47.75(34.40-92.70) \mathrm{s}$ & $47.90(30.30-400.00) \mathrm{s}$ & $0.302^{\mathrm{c}}$ \\
\hline PT & $17.00(10.00-44.20) \mathrm{s}$ & $24.40(14.50-320.00) \mathrm{s}$ & $0.0004^{\mathrm{c}}$ \\
\hline Fibrinogen & $1.65(0.79-3.61) \mathrm{mg} / \mathrm{dL}$ & $1.90(0.30-6.90) \mathrm{mg} / \mathrm{dL}$ & $0.274^{\mathrm{c}}$ \\
\hline Apgar 1 & $1.0(0.0-6.0)$ & $0.5(0.0-5.0)$ & $0.290^{\mathrm{c}}$ \\
\hline Apgar 3 & $3.0(0.0-6.0)$ & $2.0(0.0-6.0)$ & $0.116^{\mathrm{c}}$ \\
\hline Apgar 5 & $4(0.0-8.0)$ & $3(0.0-8.0)$ & $0.081^{\mathrm{c}}$ \\
\hline
\end{tabular}

$A L T$ alanine transaminase, APTT activated partial thromboplastin time, AST aspartate aminotransferase, INR international normalized ratio, $P T$ prothrombin time, $\operatorname{Tn} T$ troponin $\mathrm{T}$

${ }^{\text {a }}$ Student's $t$ test

${ }^{\mathrm{b}}$ Cochran-Cox

${ }^{\mathrm{c}}$ Mann-Whitney

\section{Discussion}

Perinatal asphyxia, leading to moderate or severe HIE, causes multiorgan injury and dysfunction not only of the brain, but also the heart, liver, kidneys, and bone marrow [19, 20]. These pathophysiological disorders are related to the severity of encephalopathy and subsequent neurodevelopmental outcomes $[21,22]$. Therefore, evaluation of severity of HIE, as well as

Fig. 1 Survival analyses

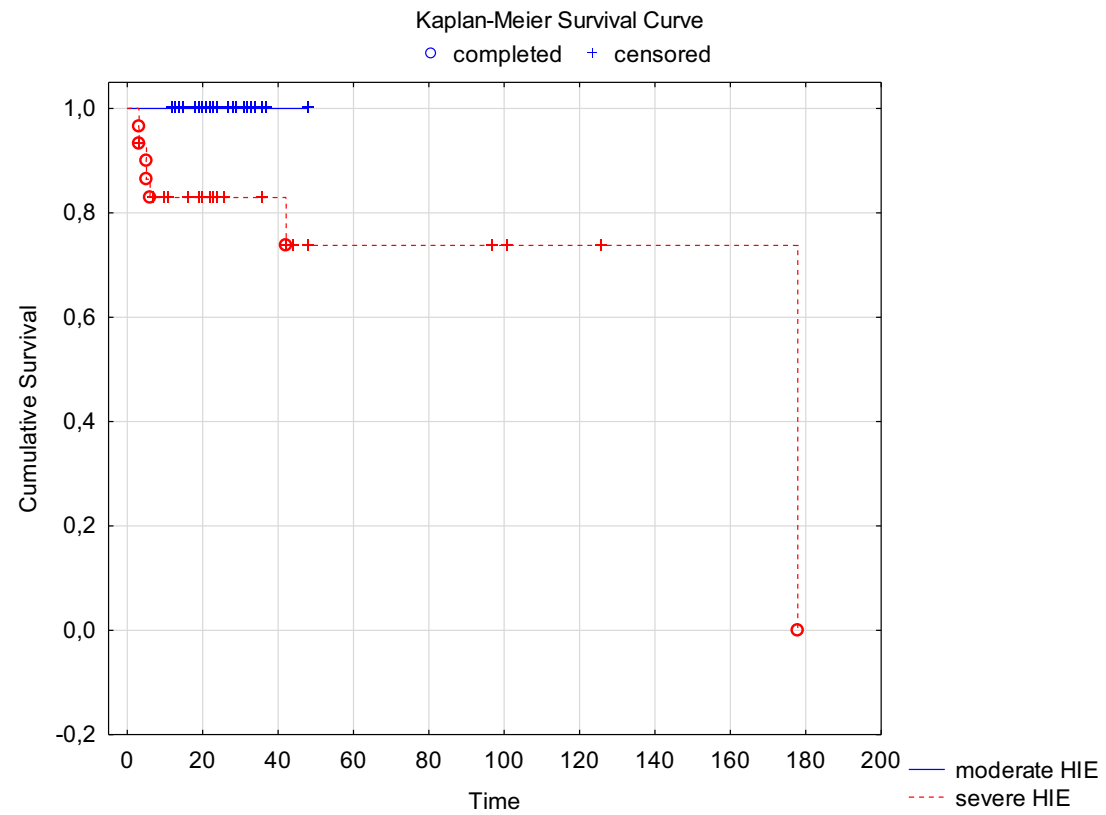


Table 3 Multivariate analyses of biochemical markers of hypoxia in HIE newborns in terms of survival

\begin{tabular}{llllc}
\hline $\begin{array}{l}\text { Dependent variable: discharge day } \\
\text { Variable cutting rate, trimmed 0-not, 1-yes }\end{array}$ & $p$ value & HR & Lower 95\% CI & Upper 95\% CI \\
$p=0.05878$ & & & & \\
\hline Lactate 2 1- $\leq 22$ 2-22-145 3->145 & 0.100826 & 0.236930 & 0.042427 & 1.3231 \\
TnT 1- $\leq 0.20$ 2-0.20-0.94 3->0.94 & 0.218603 & 2.615777 & 0.565349 & 12.1028 \\
AST 1- $\leq 93.42-93.4-552.43->552.4$ & 0.957588 & 0.914120 & 0.033404 & 25.0157 \\
ALT 1- $\leq 25.32-25.3-238.73->238.7$ & 0.285924 & 5.132402 & 0.254502 & 103.5024 \\
Creatinine 1- $\leq 0.642-0.64-1.573->1.57$ & 0.794386 & 0.820758 & 0.185817 & 3.6253 \\
Urea 1- $\leq 39.32-39.3-84.63->84.6$ & 0.306928 & 0.434016 & 0.087523 & 2.1522 \\
\hline
\end{tabular}

early detection of each potential injury in diagnosed neonates, may help predict morbidity and aid clinical management.

Different kinds of markers have been studied to identify perinatal hypoxia and neural injury [9, 23]; herein, we demonstrated differences between levels of selected biomarkers of hepatic, kidney, and myocardial injury in newborns with moderate or severe HIE treated with TH. The levels of all tested biomarkers tend to stray further from their normal range in the severe HIE group. Each of these biomarkers is discussed in the following sections.

\section{Measurements of $\mathrm{pH}$, base excess, and serum lactate}

In the presented study, besides neurological examination, serum lactate was used to predict the severity and outcome of neonatal HIE. Interestingly, we noted no significant differences between tested groups in first specimen taken in the first hour of life ( $p=0.997)$, however higher levels of serum lactate in the severe HIE infants compared with the moderate in second specimen taken at latest after $4 \mathrm{~h}$ after birth $(p=0.027)$. This is in accordance with studies of Helijic et al. [24] as well as Murray et al. [25], who suggest that first lactate value taken after birth do not predict severity of HIE. It has been demonstrated that a plasma lactate concentration taken during first $24 \mathrm{~h}$ of life was associated with moderate or severe HIE [26], and a significantly higher level of lactate was observed in infants with poor outcome compared with those with favorable outcomes [27]. We observed also significant reduction of umbilical cord $\mathrm{pH}$ in both tested groups as well as base deficit, which can also be used as a prognostic factor for unfavorable short-term outcomes in newborns, according to AhmadpourKacho et al. [28].

\section{Biomarkers of hepatic injury}

Ischemic hepatic injury occurs in about $40-60 \%$ of the diagnosed infants with HIE [8]. ALT and AST levels increase as a result of hypoxia organ damage and are sensitive markers of impaired liver membrane [29]. In our study, we showed that the levels of both biomarkers reflecting hepatocellular integrity, AST as well as ALT, differed according to HIE grade. Infants with severe HIE had significantly higher hepatic enzyme concentrations compared with that of moderate HIE infants $(p=0.0004)$. Moreover, greater differences between moderate and severe HIE babies (two times more vs. four times more) were observed in the case of ALT, which is considered to be a more specific marker for hepatic injury than AST [30]. The results of our observations are consistent with several previously published data [10, 31, 32], where authors noted not only an increase of ALT and AST concentrations but also significant correlation between their levels with the severity of HIE in newborns. Additionally, we tested PT, which is the biomarker reflecting hepatic synthetic function, and we noted longer prothrombin time in the group of infants with severe HIE $(p=0.0004)$, which confirmed the observations obtained in another cohort study [31]. Interestingly, only a few papers tested the hepatoprotective effect of the $\mathrm{TH}$ in perinatal HIE babies. A meta-analysis of six randomized controlled trials, which included 975 infants, showed no significant hepatoprotective effect of therapeutic hypothermia (relative risk 0.88 (95\% CI 0.74 to 1.05)) [13]. In turn, Muniraman et al. observed inconsistent results for individual hepatic markers, with significantly lower peak ALT concentrations in the hypothermia group, but no difference for AST concentrations and prothrombin time [10].

\section{Biomarkers of kidney failure}

If kidney function is impaired, urea and creatinine cannot be removed from the body, and their blood levels increase. Frequently impaired renal function occurs as a result of acute kidney injury (AKI), which concerns $7-72 \%$ of asphyxiated infants and alters their urinary biomarker profile [11]. It is well-known that serum urea and creatinine levels are significantly elevated in the HIE patient group in comparison with the control group $[33,34]$. In our study, there was a significant increase regarding urea and creatinine levels in the severe HIE group when compared with that of the moderate HIE group of infants ( $p=0.002$ and $p<0.001$, respectively). These findings mean that kidney biomarkers, such as urea or creatinine 
concentrations, correlated with the degree of HIE. Similarly, a rising trend in the concentrations of blood urea and creatinine as HIE staging of neonates progressed was also observed by El-Gamasy et al., Gopal et al., and Alaro et al. [35-37]. Interestingly, studies of Park et al., confirmed by El-Gamasy et al. in 2018, revealed an association between severity of HIE and the development of AKI in asphyxiated neonates [38]. Generally, the greater the degree of HIE, the higher the incidence of acute renal failure (AKI). Kaur et al. showed that AKI developed in one out of 11 infants $(9.1 \%)$ with moderate asphyxia and in 12 of 25 (48\%) with severe asphyxia [39]. Moreover, Alaro et al. noted a 15 -fold increased risk of developing AKI in HIE III compared with HIE I [37]. To our knowledge, there is no specific data focused on the protective action of TH on the kidneys.

\section{Biomarkers of myocardial injury (TnT)}

Myocardial damage occurs in 28 to $73 \%$ of neonatal asphyxia cases and is the main cause of neonatal mortality associated with hypoxia-ischemia [40]. Asphyxiated neonates have higher cardiac TnT concentrations than that of controls [39]. Several studies have confirmed that serum level of $\mathrm{TnT}$ is a specific biomarker of myocardial injury caused by neonatal asphyxia at an early stage [41]. In the presented study, we observed that severe HIE infants had approximately fourfold higher concentration of TnT compared with that of the group with moderate HIE $(p<0.0001)$. Also, Gunes et al. found that $\mathrm{TnT}$ concentrations in the first hours of life were significantly higher in HIE grade 3 compared with that in grades 1 and 2 [42]. Significant relation with increasing cTnT values and increasing grades of HIE were also observed by Joseph et al. [43]. Another study investigated levels of cardiac troponin I (cTnI) in HIE. Türker et al. demonstrated that newborns with moderate-severe asphyxia had significantly higher cTnI levels in cord blood and in venous blood compared with those with no or only mild asphyxia [44]. Moreover, Shastri et al. concluded that in asphyxiated neonates, cTnI concentrations within $36 \mathrm{~h}$ of birth correlated strongly with clinical grade of HIE [12]. Importantly, in a retrospective study by Liu et al., the level of cardiac troponin was decreased following hypothermia. The authors suggest that cTnI levels lower than $0.15 \mathrm{ng} / \mathrm{mL}$ for cooled infants at $24 \mathrm{~h}$ age predict improved outcomes [45].

\section{Levels of fibrinogen and platelets}

Thrombocytopenia, defined as a platelet count $<150,000 / \mathrm{mL}$, is associated with increased risk of bleeding, and severe thrombocytopenia (platelet count $<50,000 / \mathrm{mL}$ ) is associated with significant morbidity [46]. As a result, it is important to identify at-risk infants, and if needed, to initiate therapy to prevent complications. In most cases, thrombocytopenia develops in neonates with HIE as a result of hypothermia therapy [47]. In our results, we observed thrombocytopenia in $8 / 27$ cases of moderate HIE and in 20/29 cases of severe HIE $(p=0.003)$, which suggests a correlation between morbidity and severity of HIE. These findings were in agreement with data from Bala et al., who showed reduced platelet counts in HIE and noted that during the first $48 \mathrm{~h}$ of life it is related to severity of HIE [48].

As the endpoint, we tried to assess whether severity of HIE and selected biomarkers can be helpful in the prognosis of infants' outcomes. Although the results of our analysis showed significantly reduced survival for cases with severe HIE compared with that of patients with moderate HIE, there was no correlation between biomarkers and mortality. There are data showing that several biochemical markers, including serum S100b and neuron-specific enolase (NSE), are predictors of death, neurological abnormalities, or MRI-detected brain injury in hypothermia-treated HIE [49], but their levels depend on the timing of sampling, and their prognostic value is uncertain [20]. The limitation of our study may be due to the relatively small number of infants studied, making them underpowered for assessing correlations between given biomarkers and infants' survival.

In conclusion, the severity of the hypoxic-ischemic injury can be evaluated based on selected markers; however, their levels do not correspond with future prognosis of newborns.

\section{Compliance with ethical standards}

Conflict of interest The authors declare that they have no conflict of interest.

Open Access This article is licensed under a Creative Commons Attribution 4.0 International License, which permits use, sharing, adaptation, distribution and reproduction in any medium or format, as long as you give appropriate credit to the original author(s) and the source, provide a link to the Creative Commons licence, and indicate if changes were made. The images or other third party material in this article are included in the article's Creative Commons licence, unless indicated otherwise in a credit line to the material. If material is not included in the article's Creative Commons licence and your intended use is not permitted by statutory regulation or exceeds the permitted use, you will need to obtain permission directly from the copyright holder. To view a copy of this licence, visit http://creativecommons.org/licenses/by/4.0/.

\section{References}

1. Volpe JJ (2012) Neonatal encephalopathy: an inadequate term for hypoxic-ischemic encephalopathy. Ann Neurol 72:156-166

2. Gary DV, Hankins MS (2003) Defining the pathogenesis and pathophysiology of neonatal encephalopathy and cerebral palsy. Obstet Gynecol 102:628-636

3. Kurinczuk JJ, White-Koning M, Badawi N (2010) Epidemiology of neonatal encephalopathy and hypoxic-ischaemic encephalopathy. Early Hum Dev 86:329-338 
4. Shankaran S, Pappas A, SA MD, Vohr BR, Hintz SR, Yolton K, Gustafson KE, Leach TM, Green C, Bara R, Petrie Huitema CM, Ehrenkranz RA, Tyson JE, Das A, Hammond J, Peralta-Carcelen M, Evans PW, Heyne RJ, Wilson-Costello DE, Vaucher YE, Bauer CR, Dusick AM, Adams-Chapman I, Goldstein RF, Guillet R, Papile LA, Higgins RD, Eunice Kennedy Shriver NICHD Neonatal Research Network (2012) Childhood outcomes after hypothermia for neonatal encephalopathy. N Engl J Med 366:20852092

5. Mwaniki MK, Atieno M, Lawn JE, Newton CR (2012) Long-term neurodevelopmental outcomes after intrauterine and neonatal insults: a systematic review. Lancet 379:445-452

6. Azzopardi D, Strohm B, Marlow N, Brocklehurst P, Deierl A, Eddama O, Goodwin J, Halliday HL, Juszczak E, Kapellou O, Levene M, Linsell L, Omar O, Thoresen M, Tusor N, Whitelaw A, Edwards AD, TOBY Study Group (2014) Effects of hypothermia for perinatal asphyxia on childhood outcomes. N Engl J Med 371:140-149

7. Sarnat HB, Sarnat MS (1976) Neonatal encephalopathy following fetal distress: a clinical and electroencephalographic study. Arch Neurol 33:696-705

8. Massaro AN, Wu YW, Bammler TK, Comstock B, Mathur A, McKinstry RC, Chang T, Mayock DE, Mulkey SB, Van Meurs K, Juul S (2018) Plasma biomarkers of brain injury in neonatal hypoxic-ischemic encephalopathy. J Pediatr 194:67-75

9. Chalak LF, Sánchez PJ, Adams-Huet B, Laptook AR, Heyne RJ, Rosenfeld CR (2014) Biomarkers for severity of neonatal hypoxicischemic encephalopathy and outcomes in newborns receiving hypothermia therapy. J Pediatr 164:468-474

10. Muniraman H, Gardner D, Skinner J, Paweletz A, Vayalakkad A, Chee YH, Clifford C, Sanka S, Venkatesh V, Curley A, Victor S, Turner MA, Clarke P (2017) Biomarkers of hepatic injury and function in neonatal hypoxic ischemic encephalopathy and with therapeutic hypothermia. Eur J Pediatr 176:1295-1303

11. Sweetman DU, Onwuneme C, Watson WR, O'Neill A, Murphy JF, Molloy EJ (2016) Renal function and novel urinary biomarkers in infants with neonatal encephalopathy. Acta Paediatr 105:e513e519

12. Shastri AT, Samarasekara S, Muniraman H, Clarke P (2012) Cardiac troponin I concentrations in neonates with hypoxicischaemic encephalopathy. Acta Paediatr 101:26-29

13. Jacobs SE, Berg M, Hunt R, Tarnow-Mordi WO, Inder TE, Davis PG (2013) Cooling for newborns with hypoxic ischaemic encephalopathy. Cochrane Database Syst Rev 31:CD003311

14. Gluckman PD, Wyatt JS, Azzopardi D, Ballard R, Edwards AD, Ferriero DM, Polin RA, Robertson CM, Thoresen M, Whitelaw A, Gunn AJ (2005) Selective head cooling with mild systemic hypothermia after neonatal encephalopathy: multicentre randomised trial. Lancet 365:663-670

15. Shankaran S, Laptook AR, Ehrenkranz RA, Tyson JE, SA MD, Donovan EF, Fanaroff AA, Poole WK, Wright LL, Higgins RD, Finer NN, Carlo WA, Duara S, Oh W, Cotten CM, Stevenson DK, Stoll BJ, Lemons JA, Guillet R, Jobe AH, National Institute of Child Health and Human Development Neonatal Research Network (2005) Whole-body hypothermia for neonates with hypoxic-ischemic encephalopathy. N Engl J Med 353:1574-1584

16. Azzopardi DV, Strohm B, Edwards AD, Dyet L, Halliday HL, Juszczak E, Kapellou O, Levene M, Marlow N, Porter E, Thoresen M, Whitelaw A, Brocklehurst P, TOBY Study Group (2009) Moderate hypothermia to treat perinatal asphyxial encephalopathy. N Engl J Med 361:1349-1358

17. Shah NA, Wusthoff CJ (2015) How to use: amplitude-integrated EEG (aEEG). Arch Dis Child Educ Pract Ed 100:75-81

18. Merchant N, Azzopardi D (2015) Early predictors of outcome in infants treated with hypothermia for hypoxic-ischaemic encephalopathy. Dev Med Child Neurol 3:8-16
19. Committee on Fetus and Newborn, Papile LA, Baley JE, Benitz W, Cummings J, Carlo WA, Eichenwald E, Kumar P, Polin RA, Tan RC, Wang KS (2014) Hypothermia and neonatal encephalopathy. Pediatrics 133:1146-1150

20. Guidotti I, Lugli L, Guerra MP, Ori L, Gallo C, Cavalleri F, Ranzi A, Frassoldati R, Berardi A, Ferrari F (2016) Hypothermia reduces seizure burden and improves neurological outcome in severe hypoxic-ischemic encephalopathy: an observational study. Dev Med Child Neurol 58:1235-1241

21. Tsuda K, Mukai T, Iwata S, Shibasaki J, Tokuhisa T, Ioroi T, Sano H, Yutaka N, Takahashi A, Takeuchi A, Takenouchi T, Araki Y, Sobajima H, Tamura M, Hosono S, Nabetani M, Iwata O, Baby Cooling Registry of Japan Collaboration Team (2017) Therapeutic hypothermia for neonatal encephalopathy: a report from the first 3 years of the Baby Cooling Registry of Japan. Sci Rep 4:39508

22. Natarajan G, Pappas A, Shankaran S (2016) Outcomes in childhood following therapeutic hypothermia for neonatal hypoxic-ischemic encephalopathy (HIE). Semin Perinatol 40:549-555

23. Satriano A, Pluchinotta F, Gazzolo F, Serpero L, Gazzolo D (2017) The potentials and limitations of neuro-biomarkers as predictors of outcome in neonates with birth asphyxia. Early Hum Dev 105:6367

24. Heljic S, Hukeljic L, Terzic S, Spahovic R (2018) Serial measurements of blood lactate and early outcome of neonatal hypoxic ischemic encephalopathy after therapeutic hypothermia. Clin Res Trials 4:1-4

25. Murray D, Boylan G, Fitzgerald A, Ryan C, Murphy B et al (2006) Persistent lactic acidosis in neonatal hypoxic-ischaemic encephalopathy correlates with EEG grade and electrographic seizure burden. Arch Dis Child Fetal Neonatal Ed 93:F183-F186

26. Chiang MC, Lien R, Chu SM, Yang PH, Lin JJ, Hsu JF, Fu RH, Lin KL (2016) Serum lactate, brain magnetic resonance imaging and outcome of neonatal hypoxic ischemic encephalopathy after therapeutic hypothermia. Pediatr Neonatol 57:35-40

27. Shah P, Riphagen S, Beyene J, Perlman M (2004) Multiorgan dysfunction in infants with post-asphyxial hypoxic-ischaemic encephalopathy. Arch Dis Child Fetal Neonatal Ed 89:F152-F155

28. Ahmadpour-Kacho M, Zahedpasha Y, Hagshenas M, Akbarian Rad Z, Sadat Nasseri B, Bijani A (2015) Short term outcome of neonates born with abnormal umbilical cord arterial blood gases. Iran J Pediatr 25:e174

29. Choudhary M, Sharma D, Dabi D, Lamba M, Pandita A, Shastri S (2015) Hepatic dysfunction in asphyxiated neonates: prospective case-controlled study. Clin Med Insights Pediatr 9:1-6

30. Tarcan A, Tiker F, Güvenir H, Gürakan B (2007) Hepatic involvement in perinatal asphyxia. J Matern Fetal Neonatal Med 20:407410

31. Karlsson M, Blennow M, Nemeth A, Winbladh B (2006) Dynamics of hepatic enzyme activity following birth asphyxia. Acta Pediatr 95:1405-1411

32. Islam MT, Hoque SA, Islam MN (2010) Alteration of hepatic function: helpful to diagnose and assess severity of perinatal asphyxia. Bangladesh J Child Health 34:109

33. Gupta BD, Sharma P, Bagla J, Parakh M, Soni JP (2005) Renal failure in asphyxiated neonates. Indian Pediatr 42:928-934

34. Bhantnagar A, Bairwa AL, Meena KC (2014) Incidence of KI in perinatal asphyxia and its correlation with HIE staging. Indian J Dent Res 3:12-13

35. El-Gamasy MA, Alarabawy R (2018) Relation of serum creatinine to Sarnat scoring and brain computerized tomography of neonates with hypoxic ischemic encephalopathy. A Single-Center Experience. J Pediatr Neurosci 13:437-442

36. Gopal G (2014) AKI in perinatal asphyxia. Indian J Pharm Biol Res 2:60-65 
37. Alaro D, Bashir A, Musoke R, Wanaiana L (2014) Prevalence and outcomes of acute kidney injury in term neonates with perinatal asphyxia. Afr Health Sci 14:682-688

38. Park SS, Chung SH, Song JH (2007) The correlation between the severity of hypoxic ischemic encephalopathy and the development of acute renal failure in asphyxiated neonates. J Kor Soc Pediatr Nephrol 11:32-40

39. Kaur S, Jain S, Saha A, Chawla D, Parmar VR, Basu S, Kaur J (2011) Evaluation of glomerular and tubular renal function in neonates with birth asphyxia. Ann Trop Paediatr 31:129-134

40. Sadoh WE, Eregie CO, Nwaneri DU, Sadoh AE (2014) The diagnostic value of both troponin $\mathrm{T}$ and creatinine kinase isoenzyme (CK-MB) in detecting combined renal and myocardial injuries in asphyxiated infants. PLoS One 9:e91338

41. Jiang L, Li Y, Zhang Z, Lin L, Liu X (2019) Use of high-sensitivity cardiac troponin I levels for early diagnosis of myocardial injury after neonatal asphyxia. J Int Med Res 47:3234-3242

42. Güneś T, Oztürk MA, Köklü SM, Narin N, Köklü E (2005) Troponin-T levels in perinatally asphyxiated infants during the first 15 days of life. Acta Paediatr 94:1638-1643

43. Joseph S, Kumar S, Ahamed MZ, Lakshmi S (2018) Cardiac troponin- $\mathrm{T}$ as a marker of myocardial dysfunction in term neonates with perinatal asphyxia. Indian J Pediatr 85:877-884

44. Türker G, Babaoğlu K, Gökalp AS, Sarper N, Zengin E, Arisoy AE (2004) Cord blood cardiac troponin I as an early predictor of shortterm outcome in perinatal hypoxia. Biol Neonate 86:131-137
45. Liu X, Chakkarapani E, Stone J, Thoresen M (2013) Effect of cardiac compressions and hypothermia treatment on cardiac troponin I in newborns with perinatal asphyxia. Resuscitation 84:15621567

46. Forman KR, Diab Y, Wong EC, Baumgart S, Luban NC, Massaro AN (2014) Coagulopathy in newborns with hypoxic ischemic encephalopathy (HIE) treated with therapeutic hypothermia: a retrospective case-control study. BMC Pediatr 14:277

47. Boutaybi N, Razenberg F, Smits-Wintjens VE, van Zwet EW, Rijken M, Steggerda SJ, Lopriore E (2014) Neonatal thrombocytopenia after perinatal asphyxia treated with hypothermia: a retrospective case control study. Int J Pediatr 2014:760654

48. Bala D, Som S, Das S (2015) A study of platelet count as a marker of severity of hypoxic ischemic encephalopathy. IOSR J Dent Med Sci 14:62-64

49. Massaro AN, Chang T, Kadom N, Tsuchida T, Scafidi J, Glass P, McCarter R, Baumgart S, Vezina G, Nelson KB (2012) Biomarkers of brain injury in neonatal encephalopathy treated with hypothermia. J Pediatr 161:434-440

Publisher's note Springer Nature remains neutral with regard to jurisdictional claims in published maps and institutional affiliations. 